\title{
The Privatization of the Public Industrial Enterprises in Pakistan
}

\author{
SYED NAWAB HAIDER NAQVI and A. R. KEMAL
}

The present study examines the case for the privatization of public industrial enterprises in Pakistan, where the term 'privatization' is defined as a transfer of ownership from the public to the private sector. The focus of analysis is to compare the efficiency levels in public and private enterprises producing similar goods. It has been shown that, in general, allocative and productive efficiency is primarily associated with the quality of management rather than with the locus of ownership. The study corrects a popular misconception by showing that as some public enterprises showed losses, most of them made sufficiently large profits, and that their high rates of profit cannot be attributed to the high rates of protection. Indeed, the average rate of effective protection for industries in the public sector, as a rule, is lower than that for the industries in the private sector. Furthermore, the popular argument that the public enterprises indulge in monopolistic practices cannot be sustained because they, in fact, face competition both from the imports and the private investor; and because they typically enjoy high rates of capacity utilization. The fiscal argument in favour of privatization is also weak, because profit rates in most public enterprises tend to exceed the interest rate on public debt, so that their divestiture may increase the fiscal deficit rather than reduce it. We also argue that privatization may not lay the foundation of the so-called people's capitalism in view of low incomes of the workers and the practice of insider-trading in the stock exchanges of Pakistan. At any rate, the value-added by the public industrial enterprises is such a small proportion of the Gross Domestic Product that not many growth points can be added on account of privatization.

\section{INTRODUCTION}

The wave of privatization involving a transfer of ownership from the public sector to the private sector has hit Pakistan as well. Like many other developing countries, Pakistan has pursued a policy of privatization since the mid-Eighties. But, of late, a definite change in the mood has taken place, with a change of perception at the policy-making level. There is the widespread belief that to secure significant efficiency gains in output, the private sector should be fully associated in all sectors of the economy - especially in manufacturing, banking, energy, transport,

Syed Nawab Haider Naqvi is Director, Pakistan Institute of Development Economics (PIDE); A. R. Kemal is Joint Director at the PIDE.

Authors' Note: This is a revised version of the paper presented at the ADB/KDI Round Table on Management of Public Enterprises and Privatization held at Seoul, South Korea, 22-25 August, 1990. We are grateful to Professor Pan A. Yotopoulos for making some valuable suggestions on an earlier draft of this paper. 
communications, health, and education; that, indeed, it should be given the upper hand throughout the economy. This one-point agenda of economic reform, however, has met with limited success.

This has happened despite attempts to divest shares of public industrial enterprise units amounting to Rs 2 billion. Furthermore, the government has offered to denationalize 14 loss-making industrial units. To this end, a National Disinvestment Authority was established in 1988. The Authority has identified for divestiture fourteen industrial units which are either making a loss or earning only meagre profits. Five of the 14 industrial units identified for divestiture relate to the chemical group; three to textiles; two to steel; two to non-metallic mineral products; one to automobiles; and one to the sugar industry. However, no shares have been divested so far because of fear that off-loading shares in such large amounts may depress the share prices at the Stock Exchange. Accordingly, the Government appointed underwriters to ensure a smooth off-loading of shares, but even they could not divest them. The assets of the fourteen loss-making units amount to no more than Rs 1464 million - i.e., 0.2 percent of the total assets of public corporations, and less than 2 percent of the total assets of public industrial enterprises.

The failure to divest completely, or even partially, the public industrial enterprises is probably a reflection of the government's ambivalent attitude towards privatization; but it is also the outcome of a situation in which, due to a variety of factors, there is not enough private capital in the market to take whatever is offered for divestiture by the public authorities. The private investors in Pakistan, with a few outstanding exceptions, seem to have a short horizon, and are interested in buying only those units which are already making high profits, even if their capital costs are high. They do not seem to be interested in buying loss-making units at lower prices now and making profits on them later by improving their productivity through a more efficient management. ${ }^{1}$ But even when the private sector can be lured into buying such units, significant efficiency gains cannot be predicted with certainty whenever the underlying market structure is oligopolistic, which appears to be the case in Pakistan.

We share the view that public and private investments are essentially complementary in nature; and that while private investment holds the greatest promise in areas where productive efficiency matters, its success depends on a wellthought out programme of public investment which first provides an efficient infrastructure. Furthermore, public sector investment in those productive activities where the market "fails" due to the externalities dominating there, or where no markets

${ }^{1}$ The private sector has alleged that the government fixes the prices of units far above their replacement values. Furthermore, it is a fact that some of the public sector corporations have incurred large debts which need to be settled before such units can be made auractive to the private sector. 
exist, is essential to maximize social output - notwithstanding the contrary claims of the privatization enthusiasts who attribute every possible economic ill to the socalled phenomenon of "government failure". Also, recognizing that public sector investment - even in the productive activities - is a fact of economic life in Pakistan, it is essential that privatization should take place where it has the most promise of adding to productive efficiency and economic growth. Indeed, efficiency (and growth) considerations must be seen as the only valid grounds for privatization. And in this context, there is enough empirical evidence in Pakistan to show that changing the locus of ownership from public to private is neither a necessary nor a sufficient condition for achieving any of the avowed goals of privatization; ${ }^{2}$ even on theoretical grounds, other objectives for going private - e.g., mobilizing financial resources for the government - had better be achieved by other, more effective policy instruments. Indeed, the real-world experience suggests that across-theboard privatization, taking place mostly on ideological grounds, may prove not only self-defeating but positively counter-productive. Thus, profitable companies can as well be given over to their (not-too-worthy) competitors, exacerbating the degree of concentration in the economy; and the (apparently) defaulting enterprises may in fact be given away to friends of the regime, thus increasing the element of "crony capitalism". ${ }^{3}$

The present study seeks to evaluate the possibilities of privatization in the large-scale manufacturing sector. In order to be able to make meaningful efficiency comparisons, we contrapose efficiency levels of the public industrial enterprises with those of the private sector firms producing similar goods, where comparable data are available. We also analyze the constraints on the efficient working of public industrial enterprises. This analysis should be enough to "falsify" - in the sense of Popper (1980) - the claim that public sector industrial enterprises are inherently inefficient so that privatization must always lead to an efficient outcome.

The study is divided into five sections. Section I describes the state of affairs with respect to the public enterprises in Pakistan. Section II examines the scope for privatization in Pakistan. The general case for privatization in Pakistan's context is discussed in Section III. Section IV compares the observed efficiency levels achieved over time by public industrial enterprises with the efficiency levels prevailing in the corresponding private enterprises. It also examines the impact of government intervention on their profitability. Section $\mathrm{V}$ offers a few concluding remarks.

${ }^{2} \mathrm{~A}$ detailed analysis of the British privatization also yields roughly similar results. [See Yarrow (1986).] Hemming and Mansoor (1988) also conclude that "allocative efficiency is a function of market structure rather than ownership".

3Yotopoulos's study of privatization in Chile (1989) suggests this train of thought. 


\section{THE MANAGEMENT OF THE PUBLIC INDUSTRIAL ENTERPRISES}

There are seventy-five government-sponsored corporations in Pakistan, which held assets of about Rs 800 billion in 1987-88 - almost equal to Pakistan's Gross Domestic Product. These corporations are engaged in various fields, including banking, insurance, commerce, manufacturing, mining, oil and gas, power, construction, consultancy, mass media communications, and printing and publishing. Of these, in the manufacturing sector, there are seventy-five public industrial enterprises holding assets of Rs 56.5 billion, which accounts for 13.8 percent of the value-added and 17.9 percent of the investment in large-scale manufacturing, suggesting that these enterprises are typically capital-intensive. These public enterprises are run by eight corporations. Details about these corporations are given in Table 1, which shows that, whatever the measure of profitability adopted - i.e., rate of return on equity, paid-up capital, fixed assets or total assets or the mark-up on sales, five out of eight corporations have been reasonably profitable even from a strictly commercial point of view. These five corporations account for $\mathbf{7 1}$ percent of the output originating in public enterprises (in 1987-88). The average pre-tax rate of return on net equity, paid-up capital, and fixed assets had been 10.0,7.8, and 9.3 percent respectively, and the average markup on sales was around 9.1 percent. Excluding Pakistan Steel, which made losses partly because of the myopic accounting procedure, the average retum on net equity,

Table 1

The Indices of Profitability in Public Enterprises, $1987-88$

Public Enterprises Ex-

All Public Enterprises cluding Pakistan Steel

Rate of Return on Paid-up Capital

Rate of Return on Net Equity

Rate of Retum on Fixed Assets

Rate of Return on Total Assets

Mark-up on Sales
7.8

10.0

9.3

5.8

9.1
25.0

27.2

23.0

9.9

9.6

Source: Based on Table 9.

Notes : Retum on Paid-up Capital Return on Net Equity Return on Fixed Assets Retum on Total Assets Mark-up on Sales

: Pre-tax Profits/Prid-up Capital.

Pre-tax Profits/Net Equity.

: (Pre-tax Profits + Financial Expenses)/Net Fixed Assets.

: (Pre-tax Profits + Financial Expenses)/Total Assets.

: (Pre-tax Profits + Financial Expenses)/Sales. 
on paid-up capital, and on fixed assets has been $27.2,25.0$, and 23.0 percent respectively, which, indeed, denotes a satisfactory productive performance.

If public sector industrial enterprises have done well, it is not due to any dearth of state intervention. Although, in theory, public industrial enterprises are free to make autonomous production decisions, yet in fact the Ministry of Production intervenes in a significant way. It not only makes all the appointments and decides promotions of the senior executives and top managers in these enterprises, but it also controls the acquisition of various key inputs and capital equipment. ${ }^{4}$ In addition, the Experts Advisory Cell, created in 1980, monitors the performance, evaluation, and planning of public industrial enterprises besides recommending to the Ministry the awards of bonuses to the management and workers. The Cell is financed by imposing a levy on public enterprises. Similarly, a Special Technical Cell advises public enterprises on technical matters - especially those relating to the indigenization of the production process.

The Experts Advisory Cell evaluates the performance of public industrial enterprises on the basis of a signalling system, which was introduced in 1983. The signalling system is used to provide a mechanism for evaluating the working of the public industrial enterprises by reference to a set of criteria. These criteria relate to (i) the bases of performance evaluation; (ii) the selection of specific indicators to measure the performance of various enterprises; (iii) the assignment of weights to various evaluation criteria; and (iv) the differentiation of the good from the bad performers among the public enterprise units.

While formulating the signalling system, it has been emphasized that the performance of public industrial enterprises should be evaluated on the basis of the benefits they generate for the society as a whole, and not just on the basis of the return on equity, or some similar criteria. In general, the public industrial enterprises are not restricted to pursuing only the commercial objectives, but are mainly supposed to achieve various social objectives as well. ${ }^{5}$ Hence, it is only proper that while evaluating the performance of public enterprises, the costs associated with the achievement of the non-commercial and social objectives should also be taken into consideration. The signalling system is supposed to include such indicators as will reflect these costs as well. For example, in evaluating the profitability of public enterprise units, the system should also give due weight

${ }^{4}$ As a matter of fact, the Ministry even approves the foreign travel undertaken by the officials of public corporations to negotiate the acquisition of a plant or to acquire the technical know-how for an efficient functioning of the public industrial enterprises.

${ }^{5}$ While sufficient data are not available to ascertain the increase in cost arising from the pursuit of these social objectives, rough estimates suggest a substantial cost. For example, the industries located in the backward areas have at least a 10 percent higher production-cost. The higher employment-cost is about 5 percent of the total production-cost. 
to the expenditure incurred on research, development, and training as well as the introduction and maintenance of new products. But, at the insistence of the Ministry of Finance, the financial returns are the basic criterion for evaluating the performative efficiency of public enterprise industrial units.

Although some indicators of physical production or energy consumption are given due weight in assigning aggregate performance grades, yet, in practice, the signalling system evaluates the efficiency of public enterprise industrial units mainly on the basis of the after-tax profits earned by them. But such a procedure clearly fails to evaluate the social profitability of those public enterprise units which make losses because of the many non-economic objectives it pursues at the same time; which suggests that the efficiency levels computed by using purely commercial estimates - also in this study - are underestimates. (It may be noted that 32 out of the 75 industrial units in the public sector make losses.) The distribution of firms making losses across various corporations, the net incomes of the corporations, and their net equity are reported in Table 2.

Table 2

Profitability of Public Industrial Corporations, 1987-88

(in Million Rs)

\begin{tabular}{|c|c|c|c|c|c|}
\hline & $\begin{array}{l}\text { Number } \\
\text { of Firms }\end{array}$ & $\begin{array}{c}\text { Number } \\
\text { of Loss- } \\
\text { making } \\
\text { Firms }\end{array}$ & $\begin{array}{l}\text { Net Income c } \\
\text { Excluding } \\
\text { Financial } \\
\text { Charges }\end{array}$ & $\begin{array}{l}\text { Corporation } \\
\text { Including } \\
\text { Financial } \\
\text { Charges }\end{array}$ & $\begin{array}{l}\text { Net } \\
\text { Equity }\end{array}$ \\
\hline $\begin{array}{l}\text { Federal Chemicals and } \\
\text { Ceramics Limited } \\
\text { National Fertilizer Corp. }\end{array}$ & 14 & 7 & 164 & 294 & 529 \\
\hline $\begin{array}{l}\text { Limited } \\
\text { Pakistan Automobile Cor- }\end{array}$ & 6 & 2 & 467 & 676 & 1833 \\
\hline $\begin{array}{l}\text { poration } \\
\text { Pakistan Industrial Dev. }\end{array}$ & 15 & 6 & 293 & 488 & 827 \\
\hline $\begin{array}{l}\text { Corporation } \\
\text { State Cement Corp. of }\end{array}$ & 8 & 7 & -220 & -56 & -660 \\
\hline $\begin{array}{l}\text { Pakistan Ltd. } \\
\text { State Eng. Corp. of }\end{array}$ & 14 & 3 & 1056 & 1312 & 2032 \\
\hline $\begin{array}{l}\text { Pakistan Ltd. } \\
\text { State Petroleum Refining }\end{array}$ & 12 & 6 & -316 & -98 & 381 \\
\hline $\begin{array}{l}\text { and Pet. Corp. } \\
\text { Pakistan Steel Mills Cor- } \\
\text { poration }\end{array}$ & 3 & 0 & 127 & 293 & 765 \\
\hline & & 1 & -350 & -387 & 6336 \\
\hline
\end{tabular}

Source: Government of Pakistan (Various Issues). Financial charges in col. 3 consist of the interest on loans contracted from the govermment and commercial banks. 
Table 2 shows that, within the same industry, some firms make losses while others make profits. For example, in the chemical industry, while half of the units have made losses, the public chemical units have earned, on the average, 30.9 percent profits on equity. On the other hand, while pre-tax profits have, on the average, been negative in Pakistan Industrial Development Corporation and State Engineering Corporation, almost half of the firms in these Corporations are profitable.

\section{THE SCOPE OF PRIVATIZATION}

Before we discuss the case for privatization in Pakistan it should be kept in mind that, contrary to the popular misconception, a substantial part of the economy in Pakistan remains in private hands; the share of public sector in the GDP (in 198788 ) is only 11.6 percent (see Table 3). Large sectors of the economy - like agriculture, forestry and fishing - are entirely in private hands. However, most of the public sector investment has been in the infrastructure, including mining, and in electricity and water, which are highly capital-intensive. These are unlikely to attract much private capital anyway.

In the case of the manufacturing sector, wherein most of the privatization efforts have tended to concentrate, the public industrial enterprises account for only

Table 3

Percentage Share of the Public Sector in Various Activities

$1960-611965-66$ 1970-71 1974-75 1984-85 1987-88

\begin{tabular}{lrrrrrr}
\hline Agriculture & \multicolumn{1}{c}{-} & - & - & - & - & - \\
Forestry & \multicolumn{1}{c}{-} & - & \multicolumn{1}{c}{-} & \multicolumn{1}{c}{-} & - & - \\
Fishing & 0.0 & 0.0 & 0.0 & 0.2 & \multicolumn{1}{c}{-} & \multicolumn{1}{c}{-} \\
Mining & 3.7 & 19.1 & 24.9 & 10.1 & 93.0 & 93.0 \\
Manufacturing & 2.1 & 2.4 & 2.4 & 8.1 & 11.1 & 10.1 \\
Electricity and Water & 85.0 & 98.2 & 65.0 & 77.5 & 100.0 & 100.0 \\
Construction & 0.0 & 0.0 & 0.0 & 0.0 & 0.5 & 0.4 \\
Trade & 0.0 & 0.1 & 0.4 & 7.9 & 1.3 & 30.2 \\
Transport and Communi- & & & & & & \\
$\quad$ cation & 62.3 & 44.1 & 34.2 & 33.9 & 30.1 & 30.3 \\
Finance & n.a & n.a & 14.6 & 67.5 & 95.2 & 95.2 \\
Others & 0.0 & 0.0 & 0.0 & 0.0 & 0.1 & 1.6 \\
Share in GDP & 4.9 & 4.8 & 4.2 & 7.7 & 10.6 & 11.6 \\
\hline Share in Non-agriculture GDP & $\mathbf{9 . 3}$ & $\mathbf{7 . 9}$ & $\mathbf{6 . 6}$ & $\mathbf{1 1 . 5}$ & 14.3 & $\mathbf{1 3 . 7}$ \\
\hline
\end{tabular}

Source: Kemal (1991). 
ten percent of the value-added in that sector; while their share in the GDP is roughly two percent. Even if it is assumed that privatization would lead to a ten percent efficiency gain - though the Pakistani experience does not suggest efficiency gains so large - the increment in GDP would be no more than 0.2 percentage points; which offers only cold comfort to those who hope to achieve high growth rates by focussing on allocative efficiency alone within the manufacturing sector.

While maximum efficiency gains through the privatization of public enterprises in the manufacturing sector are modest at best, even these cannot be realized because all the assets of public enterprises need not be divested; and whatever assets are finally offered for divestiture may not be taken by the private sector for reasons that are well-known.

In order to assess the scope of privatization, it is useful to divide assets into three types of public enterprises, viz., those which make losses, those earning profits but at rates less than 15 percent, and those earning profits at rates of 15 percent or more. ${ }^{6}$ The amount of assets in each of the three types of public enterprises is shown in Table 4.

The total assets which can be divested because they make losses or earn very low rates of return amounted to Rs 27.9 billion in 1987-88. However, if Pakistan Steel is not included in the list of firms to be divested because it is too capitalintensive, and because the private sector may also exploit monopoly power due to the limited size of the domestic steel market, the total assets available for divestiture would be about Rs 4.6 billion, no more than 12.6 percent of the total fixed assets held by the public industrial enterprises. This is the upper bound on the assets which can be offered for divestiture. That being the case, the maximum efficiency gains from this source would be no more than 0.025 percent of the GDP! And even these gains may not be realized because the probability of divesting the loss-making units is close to zero in Pakistan. This is borne out by the fact that despite making a number of attempts, the government has failed to divest the 14 loss-making public units that it has offered for sale so far.

This analysis suggests that, to secure significant efficiency gains, the scope of divestiture may have to be expanded to include not only the manufacturing sector but other sectors of the economy as well.

\section{THE LOGIC OF PRIVATIZATION}

Even though they are not always explicitly specified, the following have

${ }^{6}$ The 15 percent cut-off point has been chosen because, on the margin, the government has raised loans at an average interest rate of 15 percent. Of late, the government has reduced the rate of intercst to 12.5 percent on most of the debt instruments, but the maximum rate of interest which it offers to the public on its debt instruments is still 15 percent. 


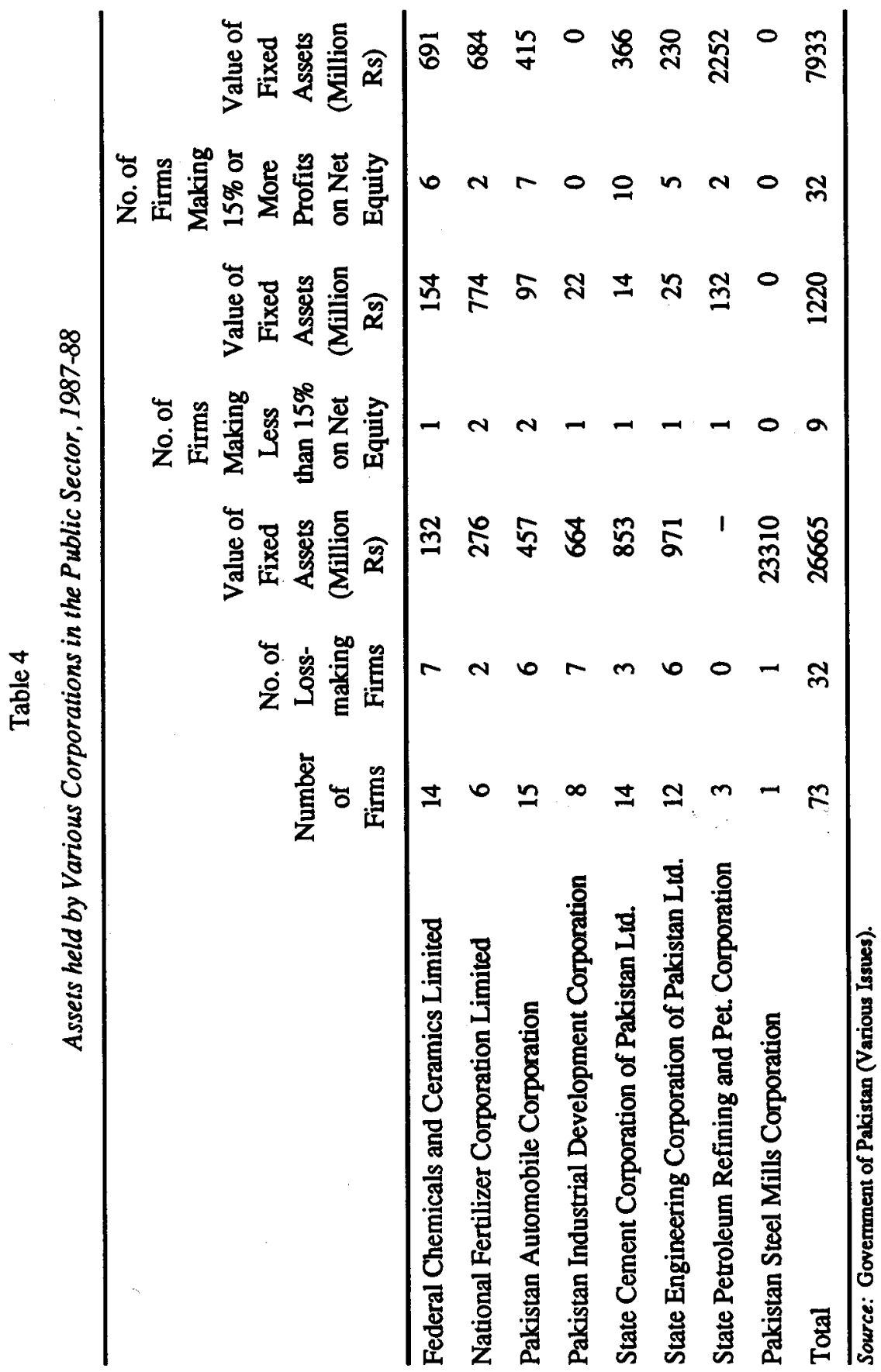


usually been suggested as the main objectives of the privatization policy: (i) to bring about a more efficient allocation and utilization of investment resources; (ii) to foster greater competition; (iii) to reduce fiscal deficits and/or to raise more funds for the physical and social infrastructure; and (iv) to broad-base the ownership of equity capital.

In this section we examine each of these objectives - in the light of the Pakistani data - as a reference point for an efficient privatization policy - i.e., that which (potentially) makes a net contribution to the value-added in the manufacturing sector on account of (allocative or productive) efficiency gains.

\section{(i) Better Allocation and Utilization of Resources}

The claim that privatization will exercise an output-raising effect on the economy is based on the presumption that the private sector, by focussing on profit maximization, secures a more efficient allocation of resources in public hands; and that such efficiency gains are substantial. [See for instance, Hanke (1987).] But these assertions are based on the belief that, in the absence of distortions in the product and factor markets, the first-best price configurations will obtain in the product and factor markets. But such a belief does not seem to rest on any solid empirical ground. ${ }^{7}$ For Pakistan, there is significant evidence to show that both the product and the factor markets are distorted, thanks to the existence of a complex network of protective devices in Pakistan's large-scale manufacturing sector. [See Naqvi and Kemal (1991).] It, thus, follows that there is no assurance, on a priori grounds, that the existing pattern of resource allocation will become more efficient by the mere passage of real resources from the public sector to the private sector through asset sales. The relevant information that exists on these matters does not suggest that the locus of ownership of productive assets - i.e., it being a public or a private enterprise - is a decisive factor in determining the level of the rate of return. As shown in Section IV of this paper, in two out of three industries where both the private and the public sectors operate simultaneously and produce similar goods, the pre-tax return on equity of the public sector units is significantly higher than that on the private sector units; but, in one case (fertilizers), the reverse also holds. Furthermore, as well-documented in the economic literature, whenever the industries in question have a substantial element of built-in externality, or when such industries are of the public-goods type - so that the free-rider's problem is serious enough, or the corresponding markets do not exist, the market-based optimum solution may lie well inside the social optimum. It is also argued that the case for

\footnotetext{
${ }^{7}$ Evaluating the findings of the existing literature on the subject de Walle (1989) concludes: “....efficiency gains from privatization will in effect be modest and limited to reductions in productive and regulatory inefficiencies" (p. 604).
} 
privatization rests on the validity of the claim that the functioning of the public enterprises is marred by substantial administrative inefficiencies; and hence privatization may potentially achieve greater allocative (or productive) efficiency. [See, for instance, Stigler (1975); Wolf (1979)]. But, obviously, in such cases, privatization per se is not necessarily an optimal policy.

\section{(ii) Fostering Greater Competition}

It is often argued that since public industrial enterprises in a specific manufacturing activity are held together by a holding corporation, they behave like oligopolists and fail to optimize output. Thus, privatization of such units is expected to promote allocative efficiency by fostering greater competition. This argument is only valid provided (a) that various public sector units of holding companies are not allowed to compete with each other; (b) that with respect to such public industrial enterprises, the government pursues protectionist policies to the extent that there is no competition from imported goods; and (c) that the private sector is not allowed to enter these industries. But, in Pakistan, none of these pre-conditions is satisfied to decide the superiority of the private sector over the public sector on a priori grounds.

First, although it is true that various public enterprises operate in accordance with the pricing policies set by their respective corporations, yet they freely compete with each other; and all the key decisions relating to production, input acquisition, etc., are made independently by each firm in the industry. Furthermore, the performance of public enterprises is evaluated - and the reward to workers and management of public enterprises given - at a unit level rather than at the corporation level.

In each industry where the public sector participates, there are a large number of firms both in the public and the private sectors. For example, in the fertilizer industry, there are five public sector units and two private sector units; and the public enterprises account for 57.7 percent of total fertilizer production. Similarly, in addition to five private industrial units, there are 14 public enterprises in the cement industry. The same is true of other industries in which the public sector enterprises dominate. (See Table 5.) In all these cases, the public sector firms effectively compete with each other and with the private sector, where they exist. Pakistan Steel is the sole example of an industry where only one (public sector) firm operates, though it produces various product categories, including billets; and in the case of a few of these products, it faces competition from the private sector.

Secondly, almost all industries in Pakistan enjoy high levels of protection, the average rate of effective protection (EPR) being 66 percent (in 1980-81). Hence, there are no valid grounds for suspecting that the higher rates of return in some 
Table 5

Share of Public Enterprises in Major Activities, 1987-88

\begin{tabular}{|c|c|c|c|}
\hline Products & $\begin{array}{c}\text { Total } \\
\text { Production } \\
\text { (000 Tonnes) }\end{array}$ & $\begin{array}{l}\text { Production } \\
\text { of Public } \\
\text { Enterprises } \\
\text { (000 Tonnes) }\end{array}$ & $\begin{array}{c}\text { Percentage } \\
\text { Share of Public } \\
\text { Enterprises }\end{array}$ \\
\hline \multicolumn{4}{|l|}{ Fertilizers } \\
\hline Urea & 1985 & 777 & 39.1 \\
\hline Other Fertilizers & 873 & 873 & 100.0 \\
\hline Total & 2858 & 1649 & 57.7 \\
\hline Cement & 7041 & 5727 & 81.3 \\
\hline \multicolumn{4}{|l|}{ Chemicals } \\
\hline Caustic Soda & 629 & 45 & 73.9 \\
\hline Soda Ash & 130 & 45 & 33.8 \\
\hline Sugar & 1771 & 18 & 1.0 \\
\hline Basic Steel & 3471 & 3471 & 100.0 \\
\hline Mild Steel Products & 568 & 241 & 42.4 \\
\hline Bicycles (000 Nos) & 661 & 152 & 23.0 \\
\hline \multicolumn{4}{|l|}{ Automobiles (000 Nos) } \\
\hline Tractors & 13.0 & 11.0 & 84.7 \\
\hline Buses/Trucks & 1.8 & 1.3 & 71.1 \\
\hline Cars/LCV/Jeeps & 35.4 & 35.4 & 100.0 \\
\hline Motorcycles/Scooters/Rickshaws & 41.9 & 1.9 & 4.5 \\
\hline
\end{tabular}

Source: Government of Pakistan (Various Issues).

public sector industrial enterprises may be due to the higher rates of protection enjoyed by them. As shown in Table 6, effective protection rates are generally relatively lower, instead of being higher, in industries where the public industrial enterprises dominate. The average rate of protection for the industries in which public sector industries participated is only 39 percent. On the other hand, industries dominated by the private sector enjoy effective protection at the rate of 70 percent.

The industries dominated by the public sector do not suffer from any higher levels of inefficiency than obtains in the private sector enterprises. The Domestic Resource Cost (DRC) of earning (saving) foreign exchange is no different for the industries where the public sector participates from those where it does not indicating that efficiency levels across industries are independent of the locus of ownership. 
Indeed, one can go a step further and state that the incidence of the worst kinds of allocative inefficiency is in the private sector rather than in the public sector. This can be seen from Table 7, where industries have been classified by various types of distortions introduced by the protection structure, as measured by the EPRs and the DRCs. It should be noted that none of the negative value-added industries is in the public sector (row 1); that out of the 60 inefficient industries (rows 2,3 and 4) only 9 are in the public sector. All in all, while 91.4 percent of the private sector industries may be classified as inefficient, the proportion of inefficient industries in the public sector is relatively smaller, i.e., 75 percent. Moreover, the level of distortion is less than that in the private sector industries; one-quarter of the industries in the public sector are penalized, while 42 percent enjoy protection at

\section{Table 6}

Effective Protection Rates and Domestic Resource Cost for Public Sector Industries, 1980-81

\begin{tabular}{|c|c|c|}
\hline Industry & $\begin{array}{c}\text { Effective Protection } \\
\text { Rate }\end{array}$ & $\begin{array}{c}\text { Domestic Resource } \\
\text { Cost }\end{array}$ \\
\hline Fertilizers" & 32 & 2.37 \\
\hline Industrial Chemicals & 77 & 2.78 \\
\hline Acids, Alkalies, Compressed Gases & 98 & 6.43 \\
\hline Petroleum Products ${ }^{\mathrm{b}}$ & -6 & 0.46 \\
\hline Cement and Cement Products ${ }^{2}$ & -3 & 1.13 \\
\hline Iron and Steel Foundries and Re-rolling & 318 & 7.76 \\
\hline Agricultural Machinery" & -20 & 1.26 \\
\hline Textile Machinery ${ }^{b}$ & 15 & 1.77 \\
\hline Metal-working Machinery" & 14 & 2.81 \\
\hline Telephone and Telex Equipment $t^{b}$ & 153 & 6.88 \\
\hline Ship-building ${ }^{b}$ & 9 & 6.21 \\
\hline Motor Vehicles" & 49 & 5.42 \\
\hline Average for Total Manufacturing Sector & 66 & 3.31 \\
\hline \multicolumn{3}{|l|}{ Average for Industries in which the Public } \\
\hline Sector Participated in $1980-81^{c}$ & 39 & 3.31 \\
\hline \multicolumn{3}{|l|}{ Average for Industries where Only the } \\
\hline Private Sector Participated & 70 & 3.31 \\
\hline
\end{tabular}

Source: Naqvi and Kemal (1991).

Notes: "Industries where the private and the public enterprises co-exist.

bindustries where there are only public enterprises.

'Excludes iron and steel re-rolling as Pakistan Steel did not start production in 1980-81. 
Table 7

Manufacturing Industries Classified by Various Types of Distortion, 1980-81

\begin{tabular}{lrcrcr}
\hline & \multicolumn{2}{c}{ All Industries } & \multicolumn{2}{c}{$\begin{array}{c}\text { Industries in which the } \\
\text { Public Sector Participates }\end{array}$} \\
\cline { 2 - 6 } & $\begin{array}{l}\text { Number of } \\
\text { Industries }\end{array}$ & $\begin{array}{c}\text { Percentage } \\
\text { Distribution } \\
\text { Types of Distortion }\end{array}$ & $\begin{array}{c}\text { Number of } \\
\text { Industries }\end{array}$ & $\begin{array}{r}\text { Percentage } \\
\text { Distribution } \\
\text { of Industries }\end{array}$ \\
\hline Negative Value-added & 9 & 11.0 & 0 & 0 \\
Inefficient and Highly Protected & 26 & 31.7 & 4 & 33.3 \\
Inefficient and Moderately Pro- & & & & & \\
$\quad$ tected & 21 & 25.6 & 5 & 41.7 \\
Inefficient and Penalized & 13 & 15.6 & 0 & 0 \\
Efficient and Protected & 4 & 4.9 & 3 & 25.0 \\
Efficient and Penalized & 3 & 3.7 & - & 0 \\
Total & 82 & 100.0 & 12 & 100 \\
\hline
\end{tabular}

Source: Naqvi and Kemal (1991).

rates less than the average effective rates of protection for the manufacturing sector as a whole.

Third, the imports of almost all the commodities produced in the public sector enterprises - including fertilizers, cement, machinery, and steel products - are neither banned nor restricted. Whereas until a few years back, some industries were exclusively reserved for the public sector, the private sector is now allowed entry into every industrial activity. It follows that, under the existing conditions obtaining in Pakistan, there is all the scope for competition - especially between the public industrial enterprises and the private sector enterprises - so that privatizing the existing public enterprises in order to promote competition is not necessarily beneficial, especially in the case of public industrial enterprises that are profitable. Viewing the matter from another standpoint, privatization would be infructuous unless the underlying market structure within the industry is predominantly competitive. However, if a firm becomes a monopoly in private hands due to denationalization, then privatization will have the perverse result of reducing the existing level of competition in such industry. ${ }^{8}$

${ }^{8}$ It may be noted that in a number of countries the privatization process has been supplemented by fiscal incentives to promote competition. The privatization of British Telecom is one such example. But if the highlight of privatization is freedom from govemment intervention, then this is hardly a shining example of privatization. 


\section{(iii) Reducing Fiscal Deficits}

Even more than securing greater allocative and productive efficiency, the urgency to reduce fiscal deficits has been the main driving force to privatize through asset sales. Pakistan has faced huge budgetary deficits. At its peak, in 1987-88, the budgetary deficit stood at 8.5 percent of the GDP. Since then, it has declined to a little over 7.1 percent of the GDP; but it is still too high. The problem of raising enough financial resources has become acute, particularly because of the government's reluctance to raise tax revenues; and because it is more difficult to raise additional resources for financing the deficit. 9

To finance the deficit, an attempt has been made to sell public industrial enterprises to private takers. But is this an optimal policy for raising revenue? Obviously, the first-best solution to reduce the budgetary deficit would instead be to increase tax revenues as a percentage of the GNP, and to contain government expenditure within the limits set by the government's ability to mobilize domestic resources. The success of privatization - i.e., the divestiture of public sector enterprises - in achieving this objective is questionable. This is because the sale proceeds from the divestiture of public enterprises reduce the budgetary deficit only if, following privatization, debt servicing falls more rapidly than do the dividends. In other words, privatization would reduce the budgetary deficits only insofar as the rate of return on equity is smaller than the rate of interest offered by the government on its debt instruments. ${ }^{10}$ But to meet this requirement, a (partial) divestiture of public enterprises does not seem to be a satisfactory policy. After all, who would like to invest in stocks with lower expected returns when the interest-bearing financial instruments of the government yielded a significantly higher rate of return?

Under these circumstances, privatization may succeed in reducing fiscal deficits if, first, the government focuses primarily on the divestiture of the lossmaking public industrial enterprises. The sale of such enterprises would eliminate the subsidies being provided to such industries to offset the losses. It would also reduce public debt and hence the debt-servicing liability. Secondly, the budgetary deficit is also reduced if the government divests public shares of those companies which promise a lower rate of profit than the prevailing rate of interest, but which have the potential of yielding higher profits if privatized.

${ }^{9}$ Domestic debt stood at Rs 380.9 billion in $1989-90$ as compared with Rs 58.1 billion in 198081. Debt-servicing charges, at Rs 65 billion (in 1989-90), constitute the biggest item of non-development expenditure.

${ }^{10}$ The govermment has raised resources by borrowing at an average interest rate of 15 percent. These resources have been invested in public enterprise equity, on which the government gets dividends. If the govemment eams profits at a rate exceeding 15 percent, the divestiture of public enterprises would cause the government's net receipts to fall more rapidly than the decline in public expenditure (debt servicing). In such a case, the deficil would increase, instead of being reduced. 
But more important in Pakistan's context is the point that even if the government divests all the industrial enterprises it owns, the reduction in the budgetary deficit from this source will be modest at best. As a rough estimate, the maximum reduction in budgetary deficit which can be expected through privatization of public industrial enterprise units - including Pakistan Steel - will not exceed Rs 5.2 billion, ${ }^{11}$ i.e., 0.6 percent of the GDP. (See Table 8.) If Pakistan

Table 8

Maximum Reduction in Budgetary Deficits through Privatization of Loss-making Units, $1987-88$

(in Million Rs)

Revenue from Revenue from Opportunity Cost the Avoidance the Sale of Fixed Assets

Corporations of Losses of Assets

@ 15\% of (2)

Federal Chemicals and Ceramics

National Fertilizer Corp. Ltd.

Pakistan Automobile Corp. Ltd.

Pakistan Industrial Dev. Corp.

State Cement Corp. of

Pakistan Ltd.

State Engineering Corp. Ltd.

State Petro. Refining and

Petrochem. Corp.

Pakistan Steel Mills Corporation

Total

Total adjusted for Pak. Steel
(1)

43.5

90.2

112.3

219.7

34.1

315.0

(2)

132.4

276.1

457.3

664.8

853.2

971.4

128.0

145.7

(3)

Source: Based on data obtained from the Amnual Reports issued by the Govemment of Pakistan the Experts Advisory Cell.

Note: The potential reduction in budgetary deficit equals the amount of losses avoided through divestiture plus the reduction in debe-servicing. By selling assets, the government's debt can be potentially reduced by the amounts indicated in column (2). Thus, debt-servicing will also be reduced by the amount indicated in column (3).

Steel is not privatized, the budgetary deficit may at the most be reduced by Rs 1.3 billion - i.e., 0.15 percent of the GDP. Even if the industrial units making a profit at the rate of less than 15 percent are divested, the budgetary deficit would only be

\footnotetext{
${ }^{11}$ All these figures relate to the year 1987-88.
} 
reduced by a maximum of Rs 1.5 billion, i.e., 0.2 percent of the GDP. Obviously, these amounts are too modest to make any significant contribution to the reduction of the large budgetary deficits in Pakistan. It does not mean that this policy instrument should not be used at all even when it works, but that it should not be used as the principal element of fiscal policy.

However, it is most unlikely that the government will succeed in divesting all the public enterprise units. The divestiture of loss-making units is rather difficult, unless losses are due only to bad management. The fact of the matter is that most of the units so far offered for divestiture have been the loss-making type, because they have either employed obsolete technology or are located in areas where due to a variety of factors - e.g., the non-availability of raw materials, an inadequate demand, or a lack of the requisite infrastructure - they cannot be profitable. Thus, partly for this reason, the private sector has not shown any interest in buying such industrial units. Furthermore, it cannot be predicted with certainty that divestiture will, by itself, make these units yield higher profits; because the returns on equity in the private sector industrial units are not necessarily higher than those offered by the public industrial enterprises.

\section{(iv) Broad-basing Ownership of Equity Capital}

The government may like to broad-base the ownership of equity capital ostensibly for reasons of distributive justice. But success here presupposes (a) that opportunities to invest in equity are not limited; (b) that the small investors have confidence in the stock exchange where the government offers these shares for sale; and (c) that small investors have sufficient investible funds to buy the shares of public industrial enterprises.

The fact is that stock exchanges in Pakistan are few and far between - they exist only in Karachi and Lahore; and the total capitalization of the shares of the firms listed there does not exceed Rs 50 billion (in 1990). Even worse, the reluctance of the private limited companies to go public has starved the stock exchanges of the necessary capital; and the practice of "insider-trading", which is allegedly prevalent in the stock exchanges, has also shaken the confidence of the investors. The reasons for a lack-lustre success of the government's divestiture policies to diversify the ownership of assets are quite obvious. First, while broadbasing the ownership of equity is a very desirable objective, it is not likely to succeed in a country like Pakistan, where per capita incomes are low and the workers have hardly any savings. Under such circumstances, even if they do buy the stocks, the workers will do so only to earn some quick profits by transferring these to the richer stock-holders. ${ }^{12}$ Secondly, a divestiture policy which provides

${ }^{12}$ For similar observations, see Yarrow (1984). 
only minority shares to the private-sector does not excite the private investor, because the control in such a case vests in the public sector management. The private sector would prefer to invest in their own business. Alternatively, the private sector may be willing to hold minority shares if combined with the private sector management. ${ }^{13}$

\section{THE LOCUS OF ASSET OWNERSHIP AND ALLOCATIVE EFFICIENCY}

The performance of public industrial enterprises has often been evaluated in terms of the criteria of commercial profitability. Needless to say, this is not an adequate criterion to judge the performance of such enterprises which come into being because of a failure, alleged or real, of the market due to externalities of various kinds. Yet, it will be seen that even on this narrower criterion, the public industrial enterprises have not done badly. To see this, we report in Table 9 five measures of commercial profitability - viz., the return on paid-up capital, on net equity, on fixed assets, and on total assets, and the mark-up (on sales).

\section{The Profitability of Public Industrial Enterprises}

The average rate of return on net equity in the public industrial enterprises in 1987-88 was 10.0 percent (Table 9, column 3). The rate of retum is lower than the interest rate on public debt. However, if Pakistan Steel is excluded, the average rate of return rises to 27.2 percent, which is significantly higher than the interest rate on public debt raised at the margin. This average, however, conceals sharp variations across various corporations, ranging from 16.6 to 52.0 percent for the five corporations, and is even negative in the case of the Pakistan Industrial Development Corporation, the State Engineering Corporation, and the Pakistan Steel Mills. Also, this ratio varies significantly across firms within a corporation. But, it is significant to note that in five out of eight corporations, the average rate of return on capital exceeds (in 1987-88) the maximum rate of interest on public debt instruments. It follows, among other things, that public industrial units have been doing rather well; and so privatization could not have helped much - certainly not by reducing budgetary deficits. No doubt, there are a few loss-making units as well; but through a change of management, the performance of even these units could have been improved significantly.

While the rate of return on net equity is the most common indicator of profitability, and is most relevant in assessing the impact of privatization on

\footnotetext{
${ }^{13}$ But the experience of $A l-G h a z i$ Tractors, cited elsewhere, shows that this strategy may also yield a limited pay-off.
} 


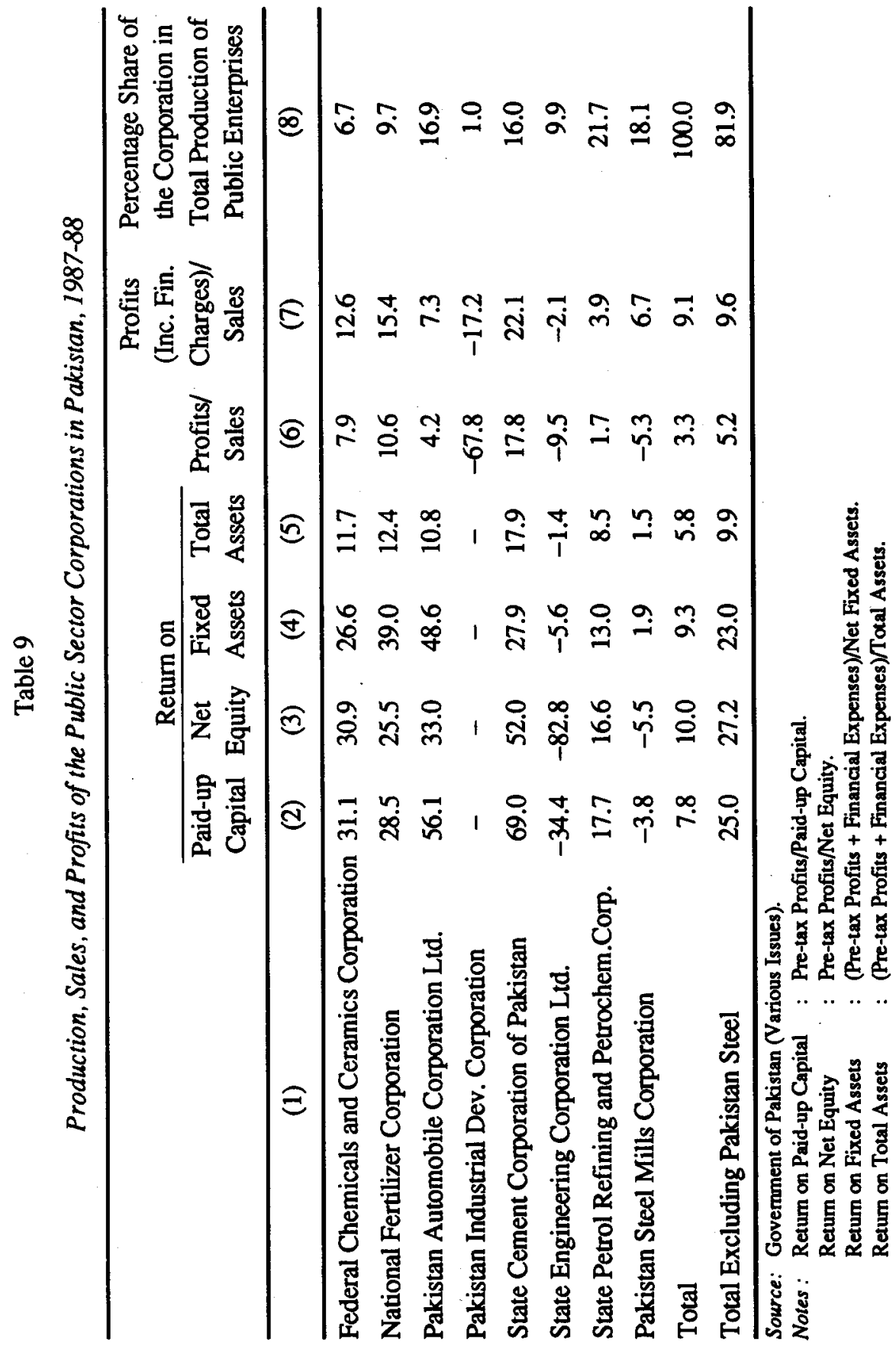


budgetary deficit, an exclusive reliance on it may distort the analysis of profitability and efficiency. This is because the value of net equity may have been eroded through accumulated losses, as has been the case with the Pakistan Industrial Development Corporation (PIDC), where it was strictly negative. In such a situation, the rate of return on paid-up capital (Table 9, column 2) is a more appropriate indicator of the profitability of a public enterprise. Once again, we note that the average rate of return on paid-up capital in the public industrial enterprises, though lower than that on equity, well exceeds the rate of interest on public debt in five out of the eight public corporations.

Another relevant indicator is the rate of return on fixed assets which, though not a measure of profitability, reflects better the efficiency of factor use. This indicator should also be used because neither the rate of return on equity nor the rate of return on paid-up capital reflects the efficiency of total capital use, as they are influenced by the financial structure of a corporation, i.e., the debt-equity ratio may vary across various corporations. Moreover, because the proportion of short-term assets in total assets may vary across industries, Table 9 shows the rate of return on total assets in addition to the rate of return on fixed assets (Table 9, columns 4 and 5). It may be noted that even though the average rate of retum on fixed assets is lower than that on net equity in the five corporations noted above, it has been rather high relative to the average rate of interest. Using this measure, we find that, for instance, while the return on equity has been negative in Pakistan Steel, the rate of return on fixed assets is positive if rather small. Similarly, the rate of return on total assets has also been quite satisfactory. Thus, by these criteria, even Pakistan Steel does not turn out to be a hopeless case, even though there is considerable room for improving efficiency there.

Since the mark-up on sales is generally taken as an indicator of profitability even if only a rather rough indicator - we present its estimates in (Table 9, column 7). It will be noted that the mark-up on sales in the public industrial enterprises, on the average, is 9.0 percent; and if Pakistan Steel is excluded, it is 9.7 percent, which is not much different from the rule of thumb generally used by the private sector, i.e., 10 percent. ${ }^{14}$ It may be noted that the profits (excluding financial charges) on sales come out to be 3.4 percent ( Table 9, column 6).

\section{A Comparative View of Public Enterprises}

While the public industrial enterprises yield dividends in excess of the interest rates, it can be argued that these profits may have been due to monopolistic practices

${ }^{14}$ Thus, Pakistan's experience contrasts sharply with Ayub and Hegstad's (1987) general finding that, within the sample countries, and sometimes within the same industries, the public enterprises have generally been less profitable than the private ones. 
and/or heavy protection. It may also be argued that privatization in these cases would yield still higher rates of return by raising their productivity levels. To assess these rival claims, the net returns on capital of the private and public firms have been compared in Tables 10,11, and 12. In order to ensure that efficiency levels are not distorted by differences in the product mix, only those industries have been considered where the private and public sectors operate simultaneously, and produce similar goods, making due allowance for product differentiation practised by different firms within an industry. The three industries satisfying this criterion are: tractors, fertilizers, and cement.

These three industries are fairly representative. They accounted for 40.9 percent of the total production, and 43.2 percent of the total sales of the public enterprises in 1987-88. We discuss the performance of each of these industrial enterprises below.

\section{The Tractor Industry}

There are three public limited companies in the tractor industry. Two of these, viz., the Millat Tractors and the Al-Ghazi Tractors, are in the public sector, while the Allied Tractors is a private sector firm. The public sector firms account for more than 90 percent of the total sales. While Millat has always been under public control, the management of $A l$-Ghazi was transferred to the private sector in 1984. The returns on equity, paid-up capital, fixed assets and total assets, the markups in these industrial units, and the corresponding production levels are given in Table 10.

The table brings out three interesting facts. First, while the public sector firms generate high returns on equity, the private sector firm has made losses. The return on paid-up-capital in the public sector tractor units is even higher. Moreover, while total returns on the fixed or total assets in the private firm are positive, the rate of return in the public firms is significantly higher. The mark-up on sales is also relatively higher in the private firms. Obviously, the return-on-capital index shows the same pattern irrespective of the choice of indicator of profitability. Secondly, the higher returns on capital in the tractor industry are not a result of protection. As a matter of fact, the industry faced a negative effective protection rate (EPR) of 20 percent because the inputs had been protected at a higher rate than the output (see Table 6). The point to note here is that, measured by the EPR, the public sector has not been favoured as compared to the private sector. Thirdly, even though the returns on equity of both the public firms fell over time, the decline in the returns earned by $A l$-Ghazi Tractors has been sharper ever since the private sector took over its management. ${ }^{15}$ Fourthly, as the last column shows, the level of efficiency in

${ }^{15}$ This result contrasts sharply with the stock argument that the reason for the inefficient working of public enterprises as compared with that of the private enterprises lies exclusively or mostly with the differences inherent in the pautem of ownership. See, for instance, Ayub and Hegstad (1987). 


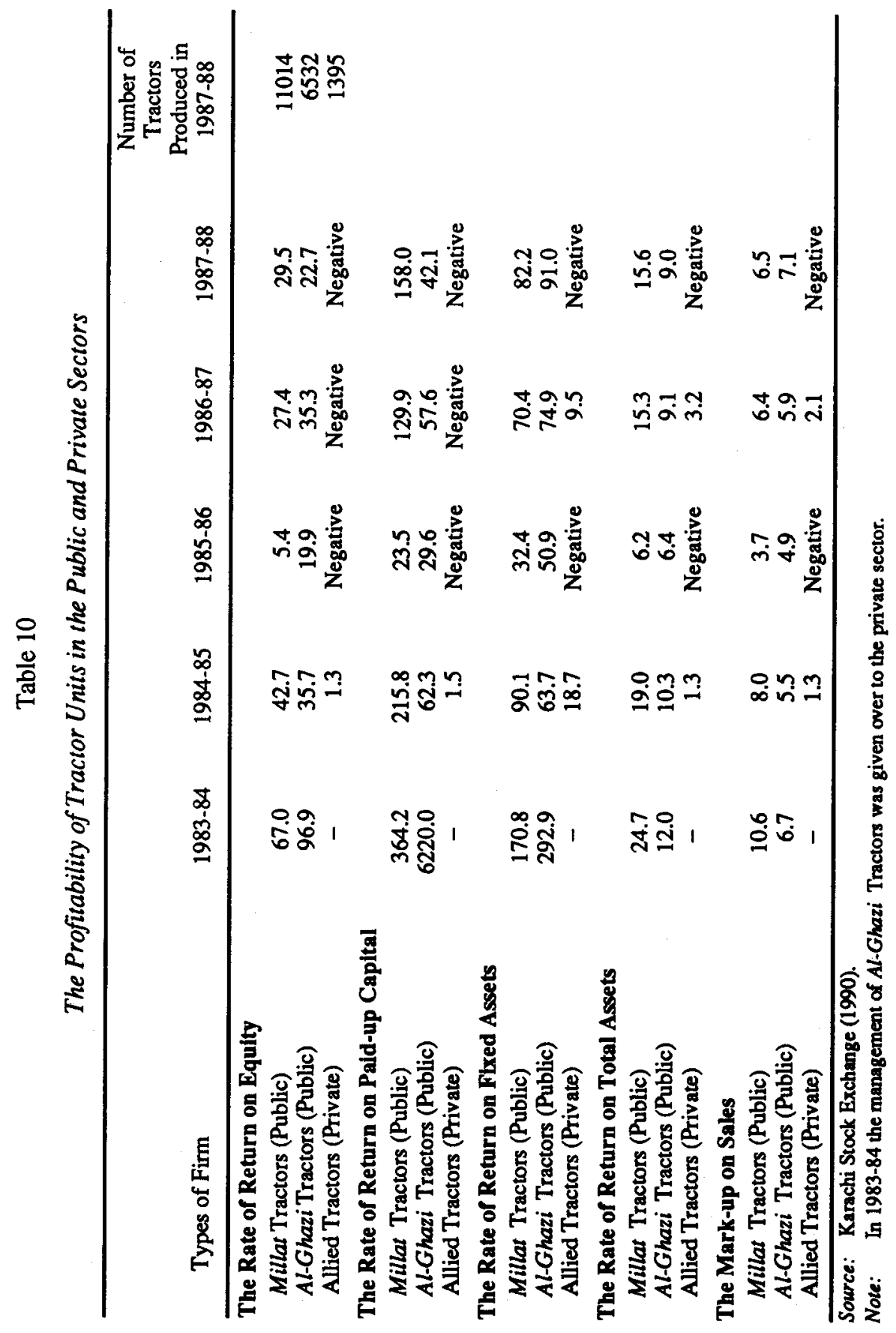


the tractor industry has varied with the scale of production. The Allied Tractors firm has had such a low level of production that economies of scale, especially in the production of components, could not have been reaped.

It may be noted that the management of $A l-G h a z i$ Tractors was transferred to the private sector mainly because, while in public control, it had failed to 'indigenize' the production process. It was expected that through privatization the indigenization process would be completed because the private management had other industrial units which produced the components for tractors. However, contrary to what was expected, the indigenization levels of the firm remained much lower than those achieved while it was still a public sector firm. ${ }^{16}$ Because of the decline in the rate of return, allegedly due to the practice of high transfer pricing of tractor components by the private manufacturing firms, the government had been considering to bring the unit back under public management in the recent past. ${ }^{17}$ Whatever may have been the government's motive, the fact is that the returns on equity declined after the firm was transferred to private hands, implying that privatization per se could not possibly have improved the existing levels of management. Furthermore, comparing the third row with the first two rows in each of the panels, the private sector firm (Allied Tractors) does not come anywhere near the public sector firms in terms of efficiency.

\section{The Fertilizer Industry}

There are, in all, seven fertilizer-producing firms - five of which are in the public sector. These control virtually the entire market of non-nitrogenous or blended fertilizers; while the public sector firms control 39.1 percent of the urea fertilizer market. The overall share of the public sector firms in the fertilizer market is 57.7 percent. The relative rates of return on capital in the fertilizer industry are shown in Table 11.

Here the pattern is different from that observed in the tractor industry. First, measured by any of the five indicators of profitability given in the table, the private sector firms in the fertilizer industry are making huge profits. The high rates of profit may be attributed partly to the protection which the industry enjoys. Though relatively low, the EPR in the case of fertilizer industry is 32 percent, unlike the case of tractors and cement, where it was negative (see Table 6, column 1). Secondly,

${ }^{16}$ However, in a conversation held with General (Retd.) Ali Nawab, Managing Director, $A l$ Ghazi, it became clear that the perception in the private sector differs sharply on this issue from that of the public sector. He asserts that the indigenization process has gone very far. Moreover, he also thinks that the higher profits in Al-Ghazi in the initial years do not relate to manufacturing operations; rather, these profits were due to the trading and not to the manufacturing activity. Thus, the decline in profits does not necessarily reflect a decline in the efficiency of manufacturing operations.

${ }^{17}$ The present government, however, wants to completely divest the unit. 


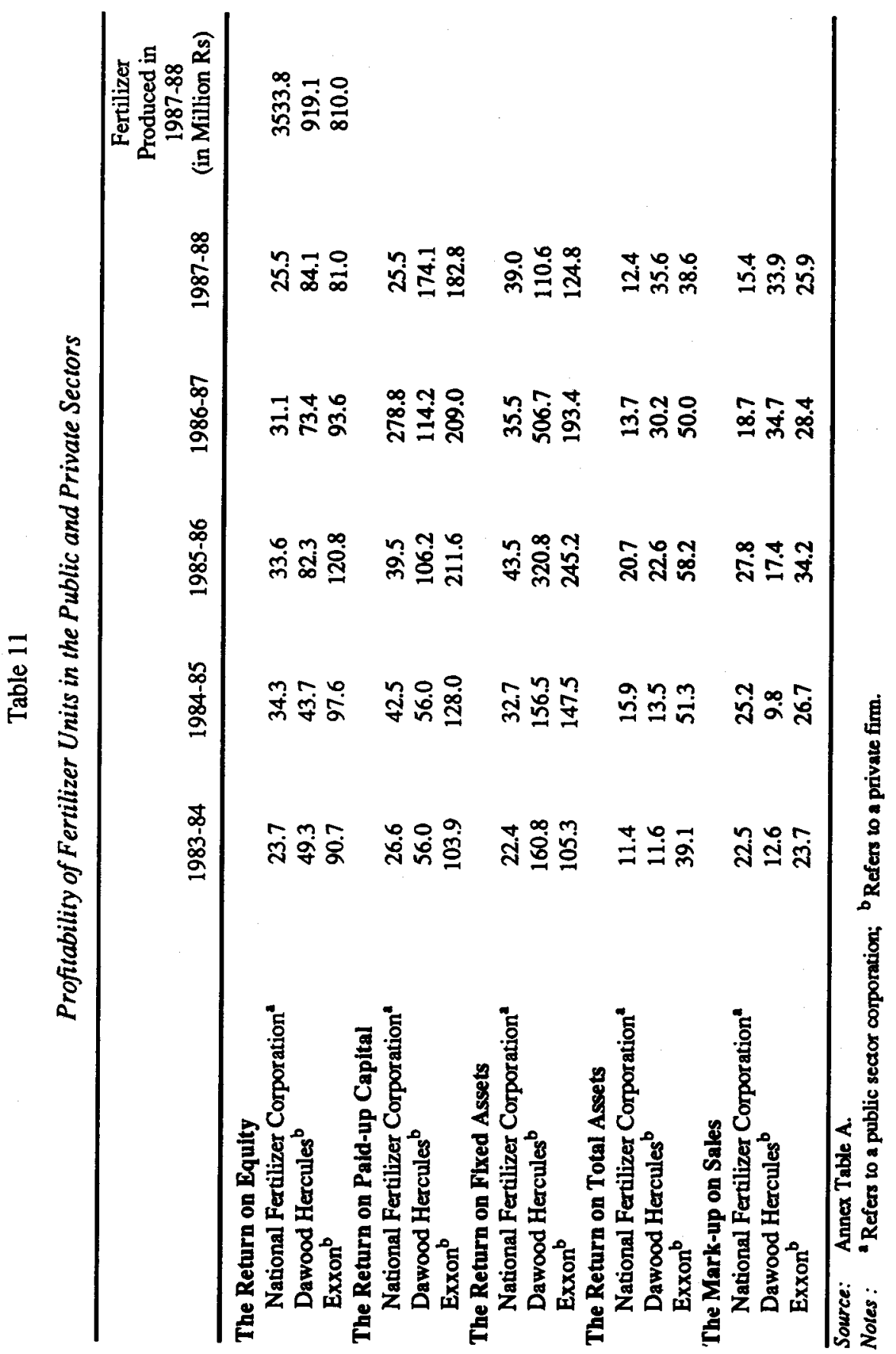


the private firms have earned higher retums even at relatively low levels of output. It suggests that the economies of scale are probably not so important in this industry (see Annexure Table A); and/or that the underlying market structure is oligopolistic. Thirdly, the returns on equity in the public sector firms, though quite high, are significantly less than the returns earned by the two private firms. This conclusion holds irrespective of the choice of the profitability indicator. Here, perhaps, is an example of an industry where private sector management has done better in terms of profitability, even with a relatively smaller access to the (fertilizer) market.

\section{The Cement Industry}

There are 14 cement-producing firms in the public sector, of which 12 are public limited companies. However, the shares of only four public sector cement factories are quoted on the stock exchange. There are five firms in the private sector as well. However, comparable data are available for only two private sector firms; while the public sector firms accounted for 81.3 percent of total cement production in 1987-88. The comparative position of cement units in the private sector and the public sector is shown in Table 12, which highlights a few interesting facts.

First, the return on equity has been rising over time. Compared to the rate of return of equity of only 23.3 percent in 1983-84, it was 52.0 percent in 1987-88. The return on paid-up capital increased from 28.4 to 69.0 percent over the same period. Similarly, the return on the fixed and total assets has doubled and the markup on sales also increased sharply from. 13.6 in 1983-84 to 22.1 percent in 1987-88. While the increase in profits may be attributed partly to the increase in efficiency, a part of it may be explained by the fact that while the cement industry faced negative protection in 1983-84, it has enjoyed positive protection since 1984-85 as the fiscal anomaly was removed in the 1984 budget (see Table 6). Secondly, the pre-tax profit on net equity is significantly higher on the average as well as in most of the publicsector firms. Only three units earned a zero or negative return (in 1987-88); but that may have been due to either locational disadvantages, or because of the very low levels of output. Thirdly, the private sector firms, though producing comparable amounts of cement, have earned a relatively lower rate of return; but these firms are undoubtedly competitive. The public sector firms come out to be the winners on the basis of all the five indicators of profitability (see Annexure Table B). However, the average return on the fixed and total assets and the mark-up on sales in the private sector firms exceeds the average return in public firms.

\section{CONCLUDING REMARKS}

It should be clear from the preceding discussion that most of the a priori arguments in favour of privatization - e.g., that it improves allocative or productive 


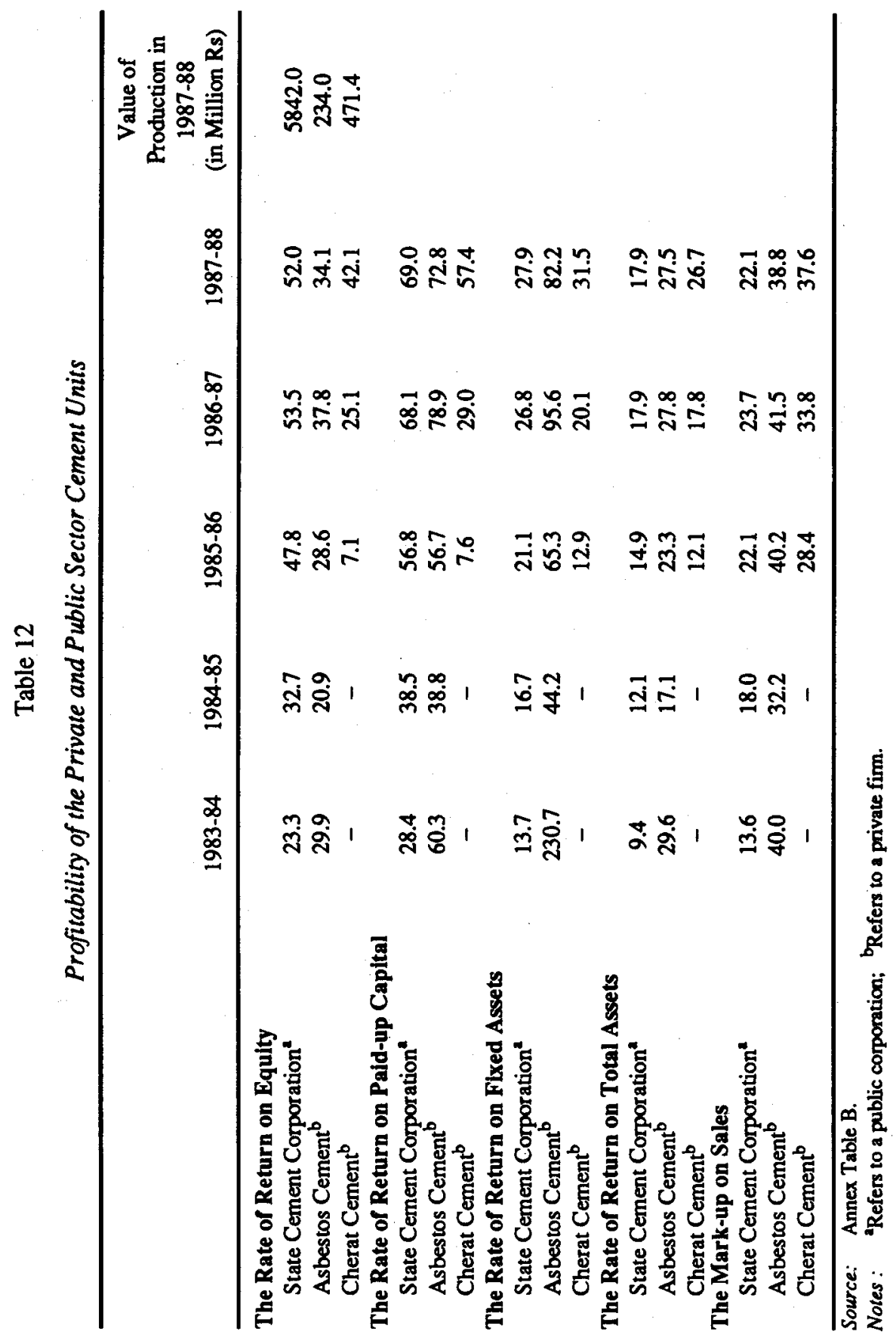


efficiency by promoting greater competition, that it helps to raise more money for the government to help solve its budgetary deficit problems, and that it lays the foundation of the so-called people's capitalism - are not convincing in Pakistan's context. Indeed, privatization may yield modest, if any, gains in allocative or productive efficiency because the (private) market structures are basically oligopolistic; the public sector's profitability is due not to the higher level of protection that it enjoys (indeed, the effective protection rates are lower for them) nor due to any restrictions placed on the entry of new firms, but to its better performance and superior productive efficiency; and the charge of the inherent inefficiency of the public industrial enterprises is based neither on good theory nor solid empirical evidence. Furthermore, the country's stock exchanges are too thin; and the 'small' potential-takers of the stocks of the divested public enterprises are basically risk-averters. This shows that the government does not normally make adequate efforts to mobilize domestic tax resources; instead, it falls back on divestiture of public assets as a desperate choice. Thus, we are left only with the socalled 'liberalist' ideology as a ground for privatization.

The basic message that comes out clearly from the preceding analysis is that changing the locus of ownership of industries is by itself neither a necessary nor a sufficient condition for an efficient operation of specific industrial enterprises. ${ }^{18}$ Indeed, the discussion in Section IV shows that both the private and public sector firms have operated efficiently as well as inefficiently, depending on the type of industry to which they belong. These results suggest very strongly that, in Pakistan, there is nothing inherently good or bad about the public sector; or even about the private sector for that matter. This point is further confirmed by Table 13, which shows that the thirty-nine units out of the sixty public enterprise units for which data are available have had capacity utilization rates exceeding 75 percent! This piece of information also confirms the point made earlier that public sector enterprises do not necessarily act as monopolists (oligopolists) restricting output and raising prices.

Indeed, in terms of growth in production, the performance of the public sector corporations has been commendable. That public industrial enterprises have not necessarily been inefficient is quite clear from the indicators, such as the pre-tax profits on net equity and the growth rates of output. Over the 9-year period from 1978-79 to $1987-88$, the production increased at a rate of 8.9 percent, which is no lower than the average growth rate of the large manufacturing sector as a wholc over the period. Furthermore, the average rate of return on equity of 10.0 percent (in 1987-88) has been no less than the average rate of interest on domestic borrowing;

${ }^{18}$ This appears to be the opinion held by a number of experts in the ficld. See, for instance, Hemming and Mansoor (1988). They conclude: “...if privatization involves no more than a transfer of activities from the public to the private sector, it may yield only limited gains". 
Table 13

Capacity Utilization Rates of the Public Sector Enterprise Units

\begin{tabular}{lrcc}
\hline & \multicolumn{3}{c}{ Number of Units } \\
\cline { 2 - 4 } Percentage Levels & $1985-86$ & $1986-87$ & $1987-88$ \\
\hline Above 100 Percent & 14 & 17 & 21 \\
Between 90 Percent and 100 Percent & 9 & 6 & 3 \\
Between 75 Percent and 90 Percent & 9 & 7 & 6 \\
Between 50 Percent and 75 Percent & 17 & 16 & 29 \\
Between 25 Percent and 50 Percent & 8 & 6 & 12 \\
Below 25 Percent & 5 & 6 & 9 \\
\hline
\end{tabular}

Source: Government of Pakistan (Various Issues).

indeed, it has been significantly higher than the average inflation rate of around 6 percent (in 1988-89).

It has also been observed that the experience of the public industrial enterprises shows marked variations both across industrial units within an industry and across different industries. These differences may have been caused by the differences in the scale of production, the quality of management, and the environment in which they operate. The favourable impact of change in management on the efficiency of operations can probably be best explained with reference to the Pakistan National Fibers (producing polyester fibre), which made a loss upto 1984-85, but the change in management in 1985 has turned it into a profitable unit since 1985-86. The success of management is even more significant because, over the 1986-90 period, there has been a substantial reduction in the protection given to the polyester industry. The pre-tax profits made by the firm are shown in Table 14.

It needs to be noted that privatization leads to a higher level of efficiency only to the extent that it enhances competition; but this does not always happen, because the presence of a large number of firms in almost all the industries where public enterprises operate offers scope for (monopolistic) competition. The only exception to this rule is Pakistan Steel, which enjoys a monopoly in most of the products it sells; though in certain other products it faces competition both from the private sector and from the imported products. Moreover, the average effective rate of protection in the public sector industries is significantly less than the average for the industrial sector. All these considerations point to the conclusion that where industrial inefficiency is the problem, steps should be taken to improve the situation regardless of the locus of ownership. The divestiture of public enterprises, mainly 
Table 14

Pre-tax Profits of Pakistan National Fibers Industries

\begin{tabular}{lc}
\hline Year & (in Million Rs) \\
\hline $1982-83$ & Pre-tax Profits \\
$1983-84$ & -73.80 \\
$1984-85$ & 5.06 \\
$1985-86$ & -37.66 \\
$1986-87$ & 68.85 \\
$1987-88$ & 83.27 \\
\hline
\end{tabular}

Source: Government of Pakistan (Various Issues).

on ideological grounds or to secure dubious economic gains, or to satisfy the sensibilities of donors and creditors, is certainly not an optimal policy. 


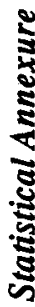

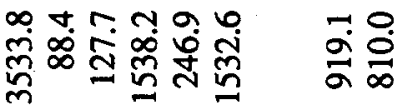

ทั丶

$n m: \frac{0}{m}$

ஸ்

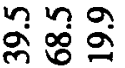

일

รั่ ช่ 


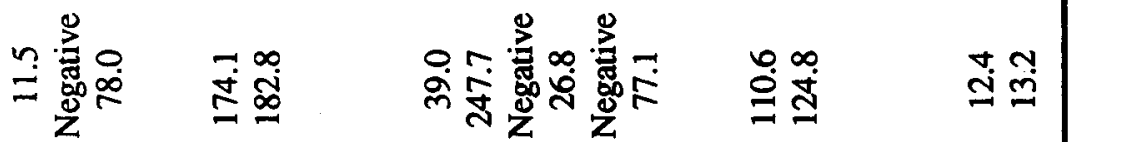

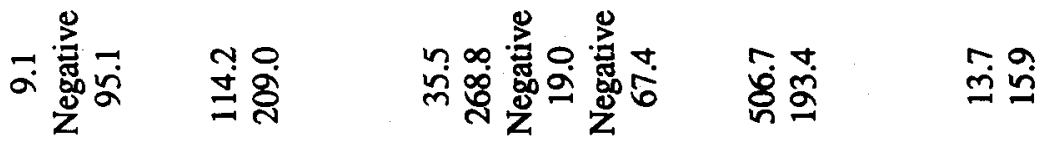

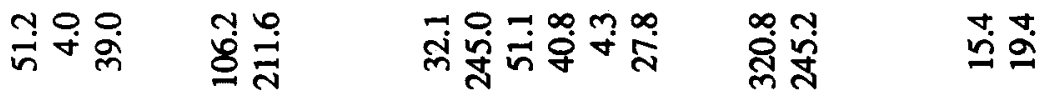

mัँ

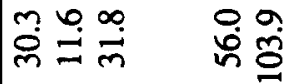

ฟู่

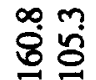

莳艺

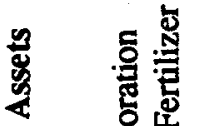

赵

1

$\leftarrow$

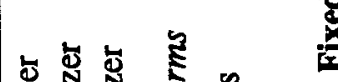

클

近㫛

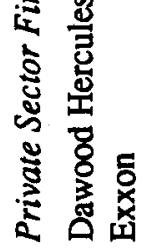

통

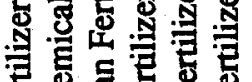

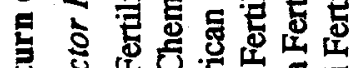

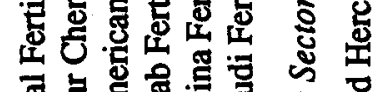

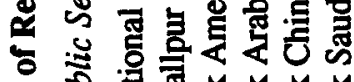

密

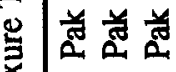

อ

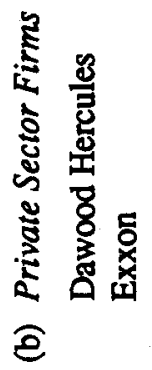

荧 동

궁 8 옹

형

旁

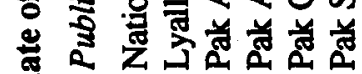

온

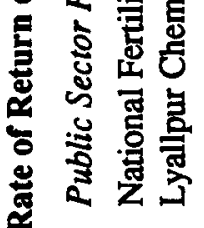

접 


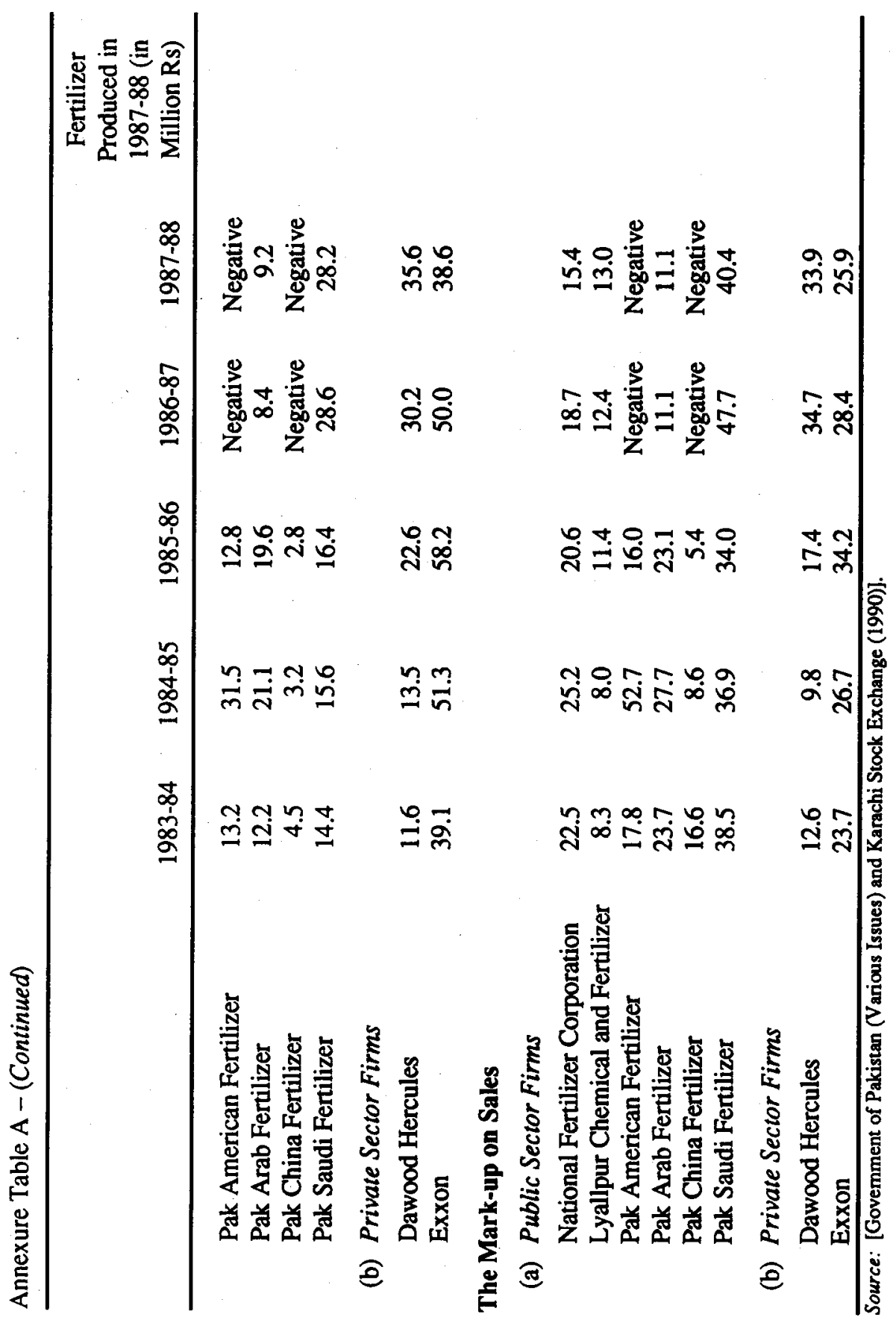




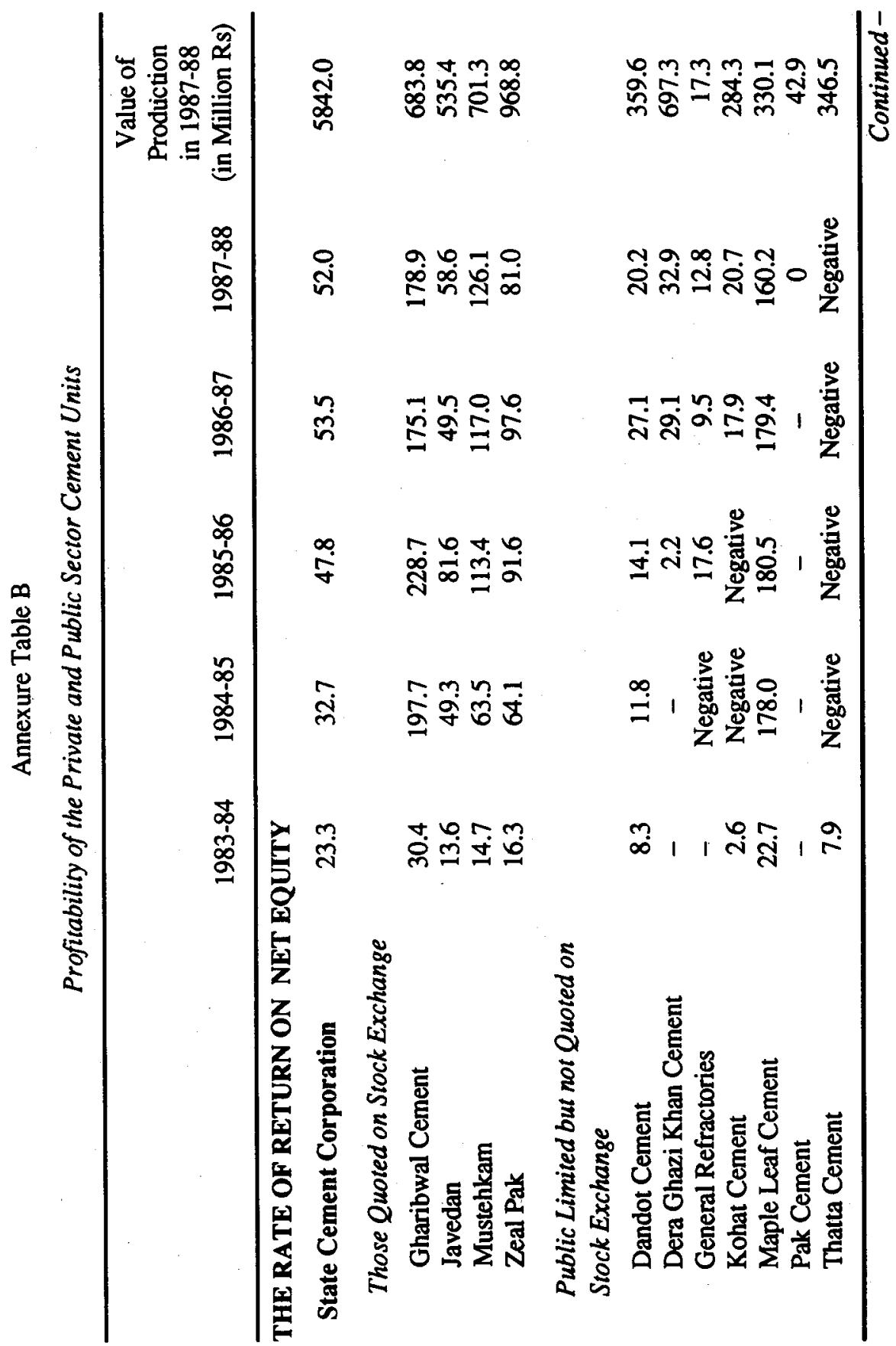




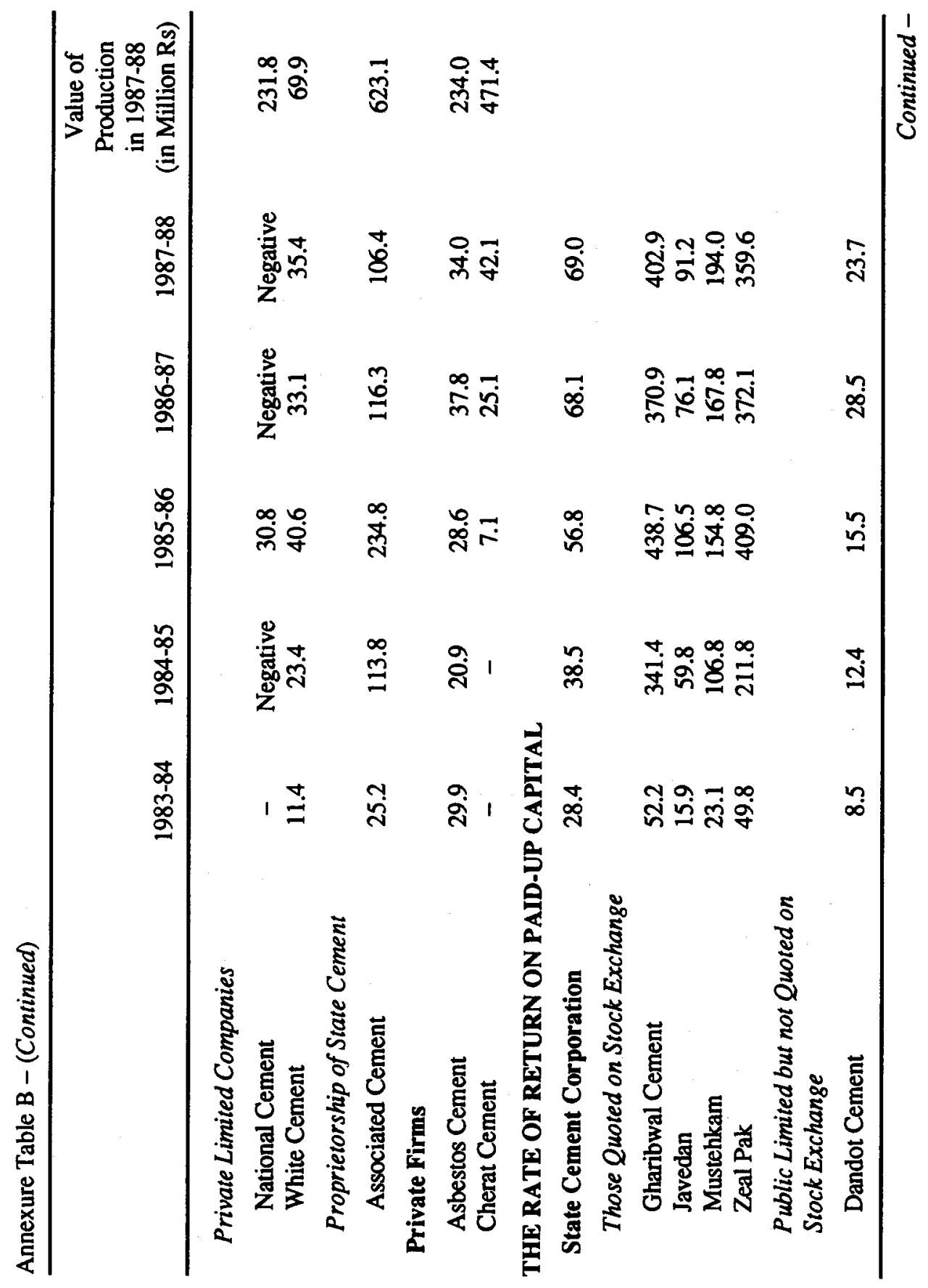




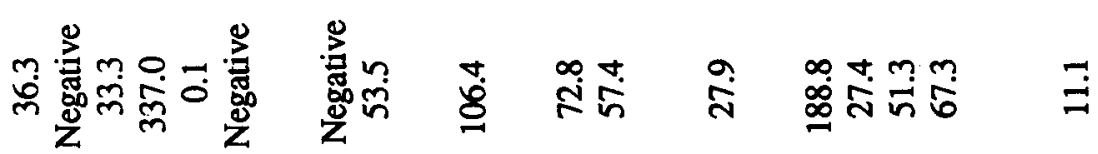

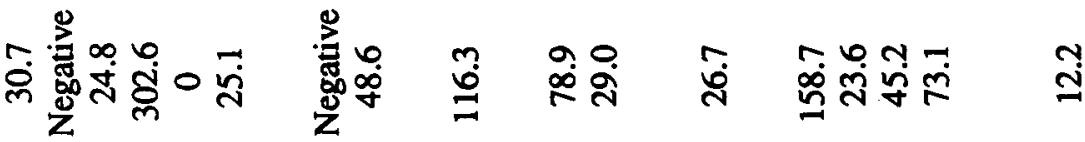

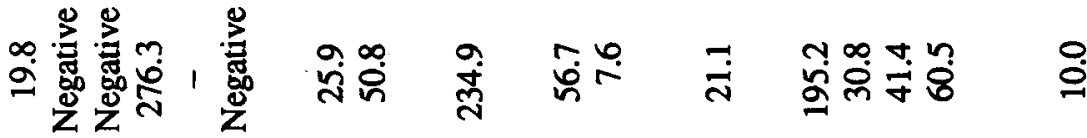

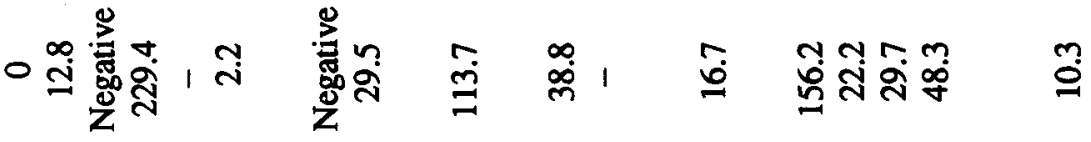

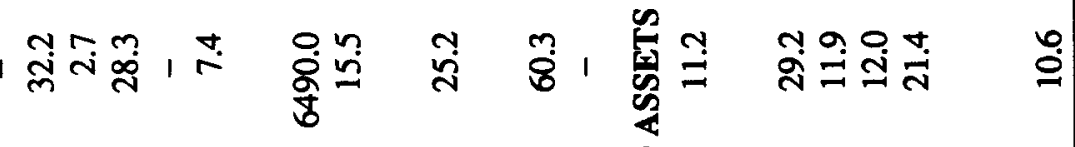

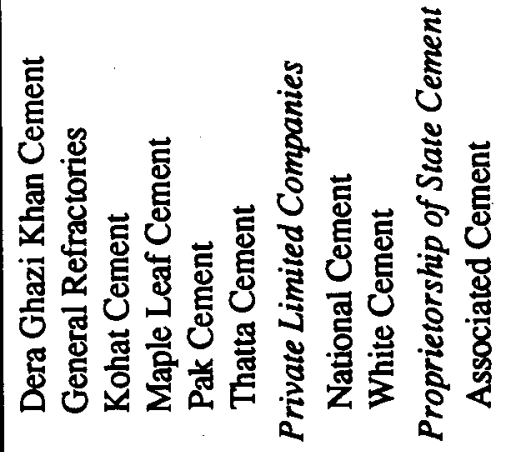
要

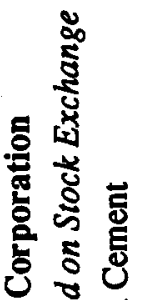




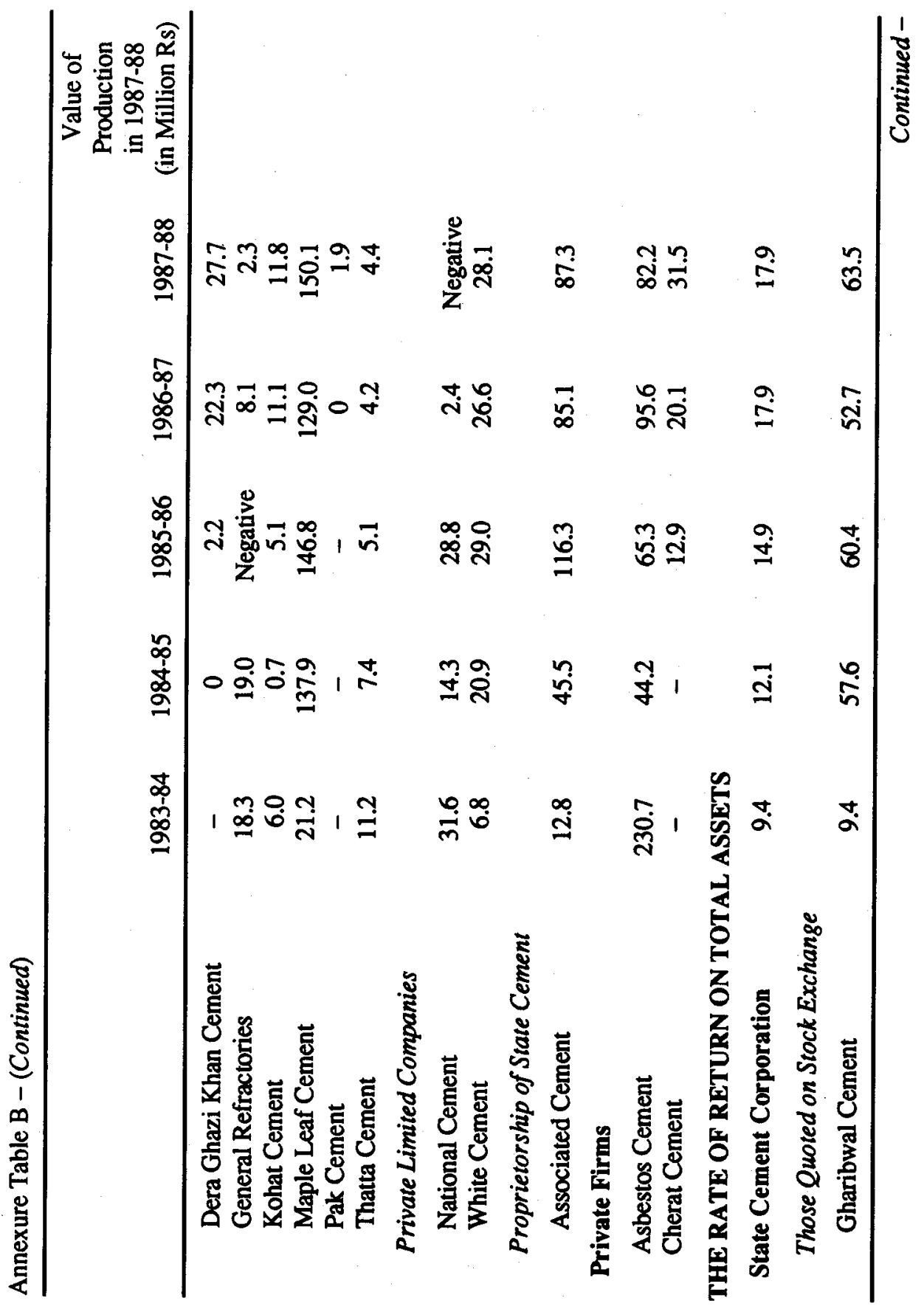




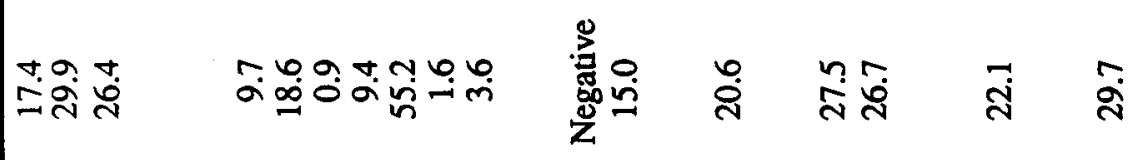

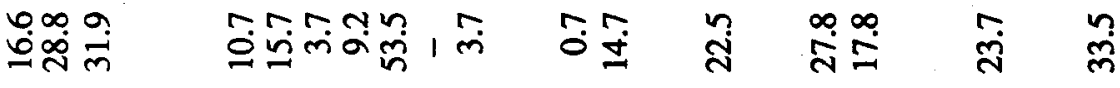

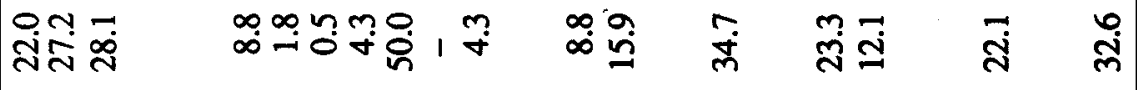

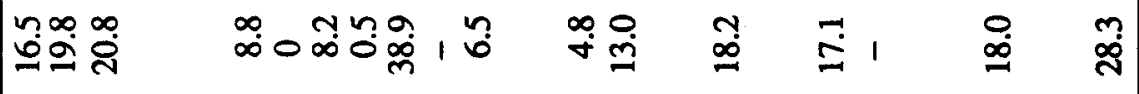

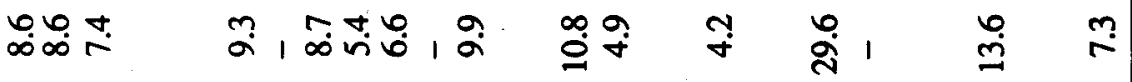

¿্ّ

$\frac{2}{5}$

范

홍

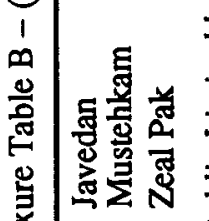

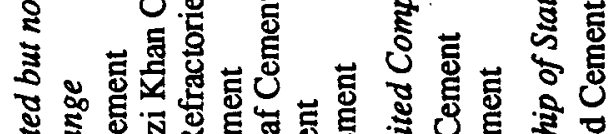

这

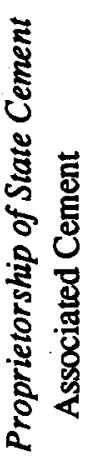

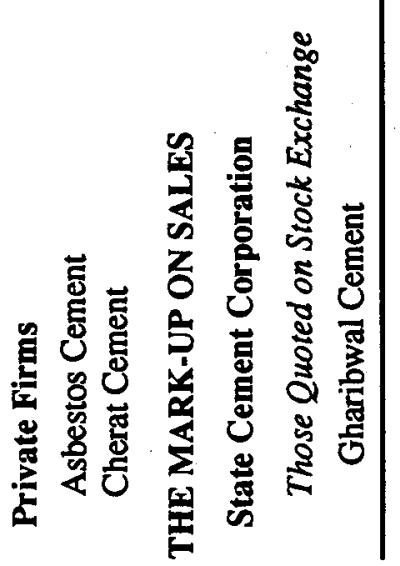




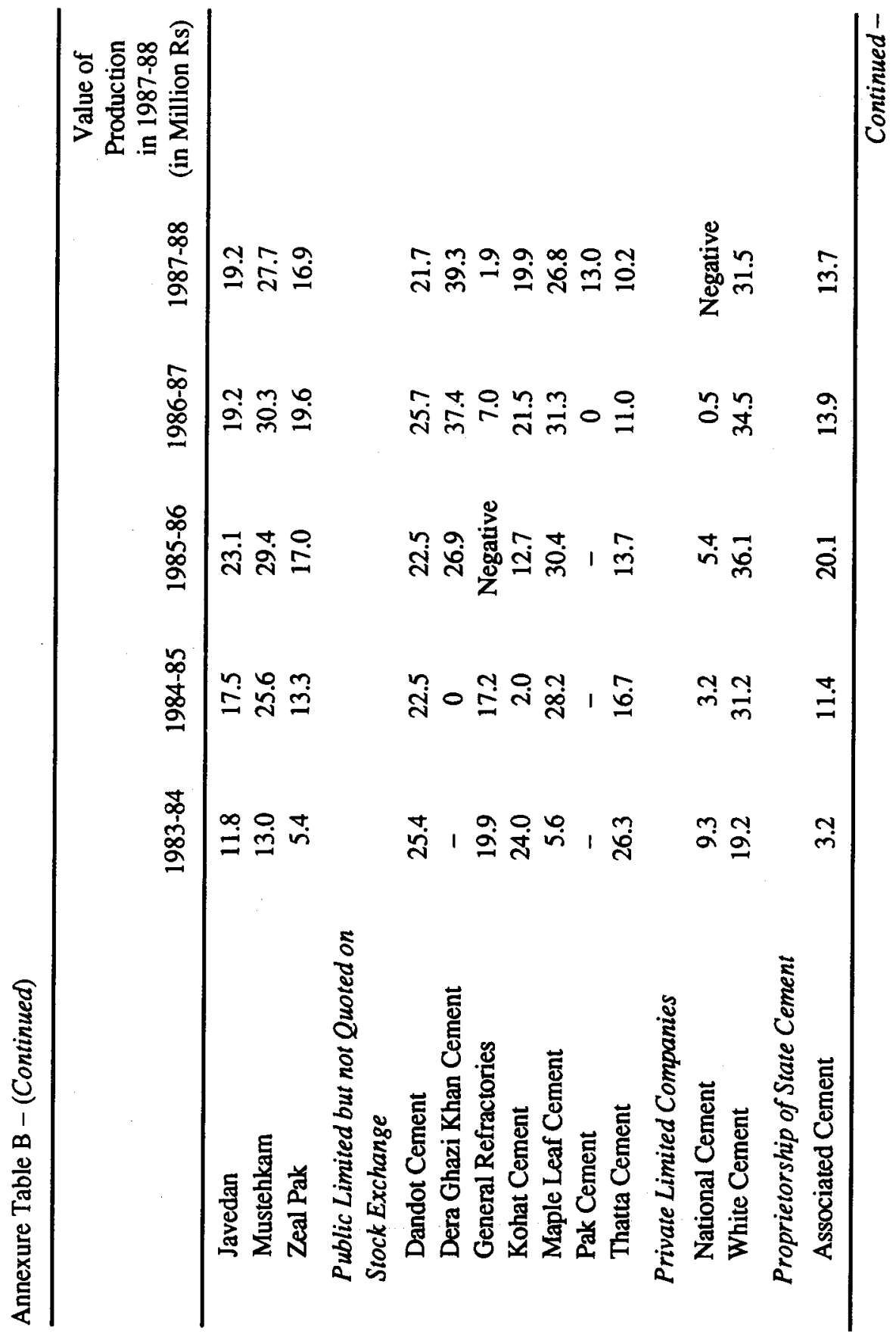




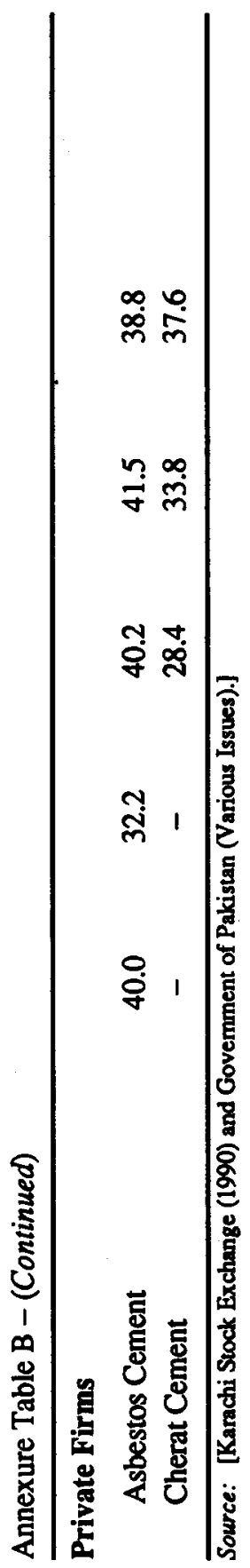




\section{REFERENCES}

Ayub, M. A., and S. O. Hegstad (1987) Management of Industrial Enterprises. World Bank Research Observer. Washington, D. C.: The World Bank.

Hanke, Steve H. (ed) (1987) Privatisation and Development. San Francisco, CA: International Centre for Economic Growth.

Hemming, Richard, and Ali M. Mansoor (1988) Privatization and Public

Enterprises. Washington, D. C.: International Monetary Fund. (Occasional Paper No. 56).

Karachi Stock Exchange (1990) Five Years at a Glance: An Analysis of the Financial Datas of the Listed Companies. Karachi.

Kemal, A. R. (1991) Privatization - The Experience of Pakistan. In V. Kaneslingam (ed) Privatisation: Trends and Experiences in South Asia. New Delhi: Macmillian India.

Naqvi, Syed Nawab Haider, and A. R. Kemal (1991) Protectionism and Efficiency in Manufacturing. San Francisco, CA: International Centre for Economic Growth.

Pakistan, Government of (Various Issues) Annual Reports 1980 - 1988. Islamabad: Ministry of Production, Experts Advisory Cell.

Popper, Karl R. (1980) The Logic of Scientific Discovery. London: Hutchinson \& Co.

Rothschild, N. M. et al. (1989) Privatization and Public Participation in Pakistan. Islamabad: International Finance Corporation.

Stigler, George (1975) The Citizen and the State. Chicago: University of Chicago Press.

de Walle, Nicholas Van (1989) Privatization in Developing Countries: A Review of the Issues. World Development $17: 5$ 601-615.

Wolf, C. Jr. (1979) A Theory of Non-market Failure. The Public Interest 55 114133.

Yarrow, George (1986) Privatization in Theory and Practice. Economic Policy: A European Forum. $1: 2$ 323-364.

Yotopoulos, Pan A. (1989) The (Rip) Tide of Privatization: Lessons from Chile. World Development $17: 5$ 683-702. 